\title{
Rescuing the other. Literary approaches towards animal's studies
}

DOI: $\underline{\text { http://doi.org/10.26758/7.1.8 }}$

Urszula Idziak-Smoczynska

Institute for the Study of Religions, Jagiellonian University, Kraków, Poland

Address correspondence to Urszula Idziak-Smoczynska, Jagiellonian University: Ul. Grodzka 52, 31-044 Kraków Poland. E-mail: urszulaidziak@yahoo.com

For love of those who are always ready to run into an endless and impossible rescue. For My mother Agata and my son Swiatopelek

"He will reply, 'Truly I tell you, whatever you did not do for one of the least of these, you did not do for me.'

Matthew 25,45

\begin{abstract}
Objectives. This paper explores the anthropological difference through the analysis of bringing rescue. To bring rescue to the other should be founded on the recognition of his suffering. But in many cases, this recognition is faulty and is based on a misunderstanding of animal/insect world.

Material and methods. Through a case study of two famous literary texts in which a human-beetle relationship appears (authored by F. Kafka and W. Gombrowicz), at the crossing of philosophy and poetry, the author of the article tries to approach as close as possible the experience of a transhumanist rescue attempt.

Results and Conclusions. The metamorphosis effectuates a true displacement in the relationship between man and animal but what Kafka describes is not the transfiguration of man into a beetle but rather the metamorphosis that affects the family.
\end{abstract}

Keywords: animal philosophy; metamorphosis; anthropological difference; strangeness; rescue.

The origin of my approach towards otherness under the figure of the animal proceeds from the interest for the fable and the parable as the margin of modern philosophy. The animal character in the fable is not the other, but the one, the same, the typical, a model of our vices and virtues. We are as slow as the turtle or as clever as the fox. Our behavior is reflected by the animals' more unequivocal expression. Following other recent antihumanist critique of the anthropocentrism of our morals, I would like to focus on the distinction between man and animal. Giorgio Agamben has advocated that this distinction is being drawn by something he called the "anthropological machine", which means that it is an effect of culture rather than a question of nature (Agamben, 2004). Therefore, his main interest is attached to zones of indeterminacy where bare life is being suspended between life and death, between law and no-law zone, created by law but at the same time suspending law, according to the logic of exception (as it is for the category of the "musulman" being a term borrowed from the Auschwitz-survivors terminology, especially Primo Levi). In this article, the study of this problematic human/animal dividing line is being observed not through the 
apparatus of law but the fabulous phenomenon of the metamorphosis. Within this process of change, a human character gradually acquires foreign features and starts to recognize in himself an animal. A human self-consciousness is embodied in the animal's carcass. The most famous reference for reflecting on metamorphosis comes from Franz Kafka's novel under this title (Kafka, 2007). Kafka's novels and miniatures have acted as a stage of a number of philosophical approaches towards displacement in anthropological philosophy. Gregor Samsa metamorphosed into a beetle, alike the ape Red Peter from the "Report to an Academy" (Kafka, 2007) can be compared to mythical heroes or creatures that inhabit the philosopher's imagination. According to Martin Puchner who has successfully approached the crisis of anthropocentric philosophy by means of the category of "negative mimesis" observed in the three literary performances of Kafka (A Report to an Academy), Coetzee (Elisabeth Costello) and Beckett (Act Without Words 1) philosophy when it comes to the question of the animal needs a literary assistance: "Philosophy should not be abandoned but crossed - to use a loaded term derived from the breeding of animals - with poetry" (Puchner, 2007, p. 26).

In order to perform such a crossing, I will engage a second literary supplement for the purpose of our reading of the metamorphosis effectuated between man and animal. It will be a scene of rescue described by the polish novelist Witold Gombrowicz in his Diary, which I will quote at length beneath:

\section{"Tuesday}

Something happened yesterday...something like a continuation of the dog at the estancia... And if I said that there is nothing equal somehow to the repugnance of the dilemma that I experienced... that I found myself where humanity must retch I could say this. I could also torment myself with it - it is really up to me.

I was lying in the sun, cleverly concealed in the mountain chain that sand forms when blown by the wind to the edges of the beach. [...] Some sort of beetles - I don't know what to call them - bustled along this desert for reasons unknown. And one of them, within my reach, lay upside down. The wind had overturned it. The sun beat on its belly, which certainly must have been unpleasant considering that this belly was usually left in the shade - there he lay, trashing his little legs - and it was obvious that nothing was to left to it except a monotonous and desperate trashing of its legs - and it was growing weak, perhaps it had been there for hours; it was dying.

I, a giant, inaccessible to him in my enormity, an enormity that made me invisible to it - I watched that trashing of legs... and extending my hand, extricated him from his agony. He moved ahead, returned to life in a split second.

I had barely done this when I noticed a little farther away, an identical beetle in an identical predicament. Trashing his little legs. I didn't want to move... But - why did you save that little guy and not this one?...why that one ...when this one...? You make one happy and the other should suffer? I took a stick, extended my hand - and saved him.

I had barely done this when I saw, somewhat farther, an identical beetle in an identical predicament. Trashing his little legs. And the sun was beating down on his belly.

I supposed to change my siesta into an ambulance for beetles in their death throes? But I had become too friendly with these beetles in their strangely helpless trashing ... and you will probably understand that once I had started this rescuing, I had no right to stop at some arbitrary point. It would have been an awful thing to do to this third beetle - to stop exactly at the threshold of his defeat. ... too cruel and somehow impossible to do....Bah! If there had been some sort of boundary between him and the ones I rescued, something that could have authorized me to stop but there was absolutely nothing, only another ten centimeters of sand, always the same bit of sand, 
"a little farther away", it is true, but only "a little". And he waved his little legs in the same way! Looking around however, I noticed "just a little" farther, another four beetles, trashing and being scorched by the sun - there was no helping it, I got up and rescued them all.

Then what should my eyes behold but the gleaming-hot-sandy plane of neighboring slope and on it five or six little trashing dots: beetles. I rushed to their rescue. I saved them.

And by this time I was so wrapped up in their suffering, I was so absorbed by it, that seeing new beetles all along the plains, ravines and canyons, an endless rash of tortured dots, I began to walk the sands as if I were demented, rescuing, rescuing, rescuing! But I knew this could not last forever - for it was not just the beach, but the entire coast, as far as the eye could see; it was sown with them so there had to come a moment when I would say "Enough!" The first unrescued beetle would have to happen, too. Which one should it be? Which one? Which one? Each time I said "this one"- I saved it, unable to bear that awful, almost vile arbitrariness - because why this one, why this one? Until I finally broke down, suddenly, easily, I suspended my empathy, stopped, thought indifferently, "Well, time to go back," and left. But the beetle, the beetle I stopped with, remained behind trashing its little legs (all of this was a matter of complete indifference to my by now, as if I had grown disgusted with the game - but I knew that this indifference was imposed upon me by the circumstances and I carried it within me like a foreign object)." (Gombrowicz, 1989, p. 38-40)

The one who hasn't experienced in his childhood an analogous dilemma of bringing rescue to beings who are counted in thousands and who pushed by an incomprehensible death drive urge to the water or through the sand, contradicting any logic of our own, must read this fragment with indifference. It will seem to him an extravagance of a pretentious writer. Nevertheless, this long quote is important because of the presence of a distinctive brace enveloping this experience, a brace of self-attention or self-consciousness that doesn't stop working. "I could also torment myself" or not torment myself with it - "it is really up to me". At the beginning Gombrowicz announces those two possible attitudes toward the experience he is bound to describe but ultimately, he ends with something that stands in opposition to this kind of self-control. The "indifference" that suddenly appears in order to displace the torment is all the same "foreign". The concern about the fate of every little beetle and the band-like mercy offered must, however, come to an end sometimes and seems at the discretion of the writer. But the indifference is welcomed as something foreign.

The rescue never comes to an end in abstracto, but always on one of the beetles, the one and not the other, who/which becomes at once the one, the first one who has been denied help offered to others. Although help has been denied because of the multitude, because of this "endless rash of dots", the one, the first one - "which one? Which one?" becomes the touchstone upon which stumbles the so-called listlessness.

Franz Kafka was well acquainted with both the torment of this rescue and the suffering of its disruption. He almost trained the power of such a self-imposed distress. But what fascinated him most was the foreignness that uses to appear at the end. It is specifically visible when in Kafka's miniatures and parables rather than popular zoomorphic figures some entomomorphic beings or hybrids like Odradek appear. They do not come to simplify the dramaturgy of the fiction; on the contrary, they make it more obscure as we are unable to specify the figure of the main character. We lose the ability to recognize easily his/its shape, to assign him/it to a specific species.

Our experimentum mentis will consist in reading Kafka's Metamorphosis as a lenticular reflection of the experience described by Gombrowicz. Let's begin by the fact that in the "Metamorphosis" the foreignness appears not at the end but at the very beginning in this "most risky moment, when the day falls on you", using Bulgakov words. In spite of hasty parallels, it is not the metamorphosis "into a monstrous cockroach" (Kafka, 2007, p.87) that surprises most Gregor Samsa. 
At the beginning, a much more important problem is the fact of his oversleep and consequently his being late for work. If the metamorphosed Gregor Samsa could continue to be a solid and devoted employee of the company, which is a rarely coming home traveling salesman, he wouldn't even pay attention to his new appearance. Nevertheless, "his numerous legs, pathetically frail by contrast to the rest of him, [that] waved feebly before his eyes" were the main obstacle that impeded the possibility of jumping out of bed and catching the next train. The dramaturgical tension inside the main character is built on the axis of working and sleeping, while his entomo-morphic form is recognized only when it becomes an obstacle for one of those activities.

Meanwhile, outside Gregor Samsa's room, the foreignness amplifies in the same rate. And it is also the question of time that is its first generator. The callings at first innocent and calm become remarkably obsessive. The family can be justified by "uncertainty", but it is rather an uncertainty about its main provider, rather than about a son or a brother. The plaintive voice of the sister is as much premature as the visit of the chief clerk. The mistrust and the mechanisms of control are coming together in the immediate process of alienation. Its culmination is achieved yet before the metamorphosis of Gregor Samsa becomes explicit, in the laconic words of the chief clerk: "Something's fallen down in there". If we consider Gombrowicz's scene as a macro scale analogy for the Metamorphosis, Gregor becomes a beetle because of this quasi-suicidal temptation of finding oneself on a sandy dune in an endless and risky rush. The fate of a beetle corresponds to the fate of a traveling salesman who is suddenly stopped overturned by the wind. Only the fact of lying on the back creates a barrier that impedes Samsa from reaching the successive trains according to the timetables that he used to study in the evenings. "He would have used his arms and his hands to push himself up; but instead of them, he only had all those little legs continuously moving in different directions, and which he was moreover unable to control". In this loneliness of an undefined species - a traveling salesmen, who locks himself in his room even in his family house the idea of a possible help coming from outside finally appears "two strong people [...] would easily suffice" (ibid., p.93). "Rescuing, rescuing, rescuing!" (Gombrowicz, 1989, p. 39) - alas, such a spontaneous interspecies bond does not emerge.

When we observe the juxtaposition of those two pieces of literature a geometrical reflection seems to appear. In Gombrowicz, the giant is the one who rescues, whereas in Kafka it is the beetle that is gigantic and needs two strong people to get it out of bed. When Gombrowicz, "a giant, inaccessible [...] in [his] enormity", gets up, Samsa swings "powerfully swung himself right out of bed" (Kafka, 2007, p. 94). To the main dilemma of Gombrowicz about when to stop the ceaseless rescue of beetles corresponds the troubling thoughts of Gregor Samsa himself. The first movement of the extended hand to save the first noticed beetle is as much unreflective than the acceptance of its new appearance and the readiness to go back to work of the metamorphosed salesmen. The disturbance of this first naïve approach comes when it occurs - against Samsa's expectation that his capacity to talk and to think is idiosyncratic and cannot lead to communication with the rest of the family. "Now" said Gregor, "in the knowledge that he was the only one present to have maintained his equanimity" (ibid., p.101) - this expression of calm control, drawing conclusions and planning that is inaugurated by this "now [then]" is a form of bizarre friendliness that appears too in Gombrowicz. "I had become too friendly with these beetles" is expressed by a more striking "feeling at home" (pl. zadomowienie) in the polish original (Gombrowicz). Gombrowicz says explicitly - however awkward it may sound - "I felt too much at home with those beetles". For the sake of the Metamorphosis, we could, therefore, paraphrase this as follows "I felt too much at home within this beetle". "[F]or the first time that day, he began to feel alright with his body; the little legs had the solid ground under them; to his pleasure, they did exactly as he told them; they were even making the effort to carry him where he wanted to go; and he was soon believing that all his sorrows 
would soon be finally at an end." This pulling oneself together, rediscovering one's mobility, one's sensibility for pain, taste, hearing, etc., runs very quickly in the process of experiencing. It proves that the metamorphosis is a dynamic process and that it still proceeds "[f]or it was true to say that with each passing day his view of distant things grew fuzzier; the hospital across the road, whose ubiquitous aspect he had once cured, he now no longer even saw, and if he hadn't known for a fact that he lived in the leafy, but perfectly urban Charlottenstrasse, he might have thought that his window gave on to a wasteland where the grey sky merged indistinguishably with grey earth" (Kafka, 2007, p. 115) - "the gleaming-hot-sandy plane of neighboring slope" (Gombrowicz, 1989, p. 39).

The story is thus conducted in two languages, the one of friendliness toward the newhimself of Gregor Samsa and the one the growing alienation of the other inhabitants of his family house. The whole metaphoric of doors and windows opened and slammed shut or left open as "happens at times when a great misfortune has taken place" (Kafka, 2007, p. 98).

Indeed, unexpectedly, the metamorphosis opens the house of the Samsa family. Up to this time, the permanent absence of Gregor Samsa traveling for work has let the family live in a sort of isolation. None of the other members of the family was working and it is only with the metamorphosis that each of them is forced to establish contacts with the world in order to make a living. Gregor's "father running out to get breakfast for the little bank officials, his mother hurling herself at the personal linen of strangers, his sister trotting back and forth behind the desk, doing the bidding of the customers" (ibid., p.129). Besides this, some tenants are introduced inside the apartment and though Gregor is still isolated, to the most intimate moments of the family life join some strangers "they sat up at the table where formerly, Gregor had taken his meals with his father and mother" (ibid.). Nevertheless, the most foreign body inside this organism "the old charwoman", who was coming twice a day to relieve the mother and the sister from the hardest duties, not only knows about Gregor but without any real curiosity keeps opening the door of his room according to her caprice. It is on her robust boned and thick-skinned person that the subsequent stages of the metamorphosis take place. For when Gregor listened to her impertinent words addressed to him ("will you take a look at that old dung-beetle") - he never responded, "but [...] stayed just exactly where he was" as if the door had never even been opened. This immobility is the answer for the language which is intentionally adapted to his new figure, the language of words that "she probably thought were friendly" (ibid., p.131), words of vulgar forwardness, that a maiden can address only to some degraded animals from the house where she serves.

In Samsa's attitude, a human reaction of offense is fused with an animal's immobility out of fear. It is the beetle that despises the woman, despite the fact that she is the only one who addresses him personally (if we agree that the questions she is addressing him, although rhetorical, are still questions). "Aren't you coming any closer, then?", she shouted, "intending not to close her mouth until the chair in her hand had been slammed down into Gregor's back." This last convolution of the metamorphosis ends with a short and pointless "brief look in on Gregor". While he is already dead she continues her provocative play with him. Seeing him so still, she considers he is pretending "playing the martyr" as "she attributed all possible understanding to him". Between this recognition of human abilities à rebours (understanding, pretending) and the first sob of the sister, who didn't yet know anything beyond the fact that her brother had a delay for work and didn't want to open the door, a reversal of the inhuman call for rescuing takes place. "[The sister] was clever, she was already in tears while Gregor was still lying peacefully on his back". The friendliness and the alienation must act dialectically. When Gregor decides to show himself to his family he speculates on the following alternative: 
"If they were shocked, then Gregor would have no more responsibility and could relax. Whereas if they took it all calmly, then he wouldn't have any cause for agitation either, and if he hurried, he might still get to the station by eight o'clock" (ibid., p.98). In the first moments of awakening, it seems that nothing beyond this calm is required in order to bring this situation to normality. But Gregor's calm is conditioned by the acceptance both of the family and of the company. So far it was all about the delay and Gregor Samsa was rightly reflecting about why is he "condemned to work for a company where the smallest lapse was greeted with the gravest suspicion?" (ibid., p.93-94). With the coming of the chief clerk in person, the family becomes sucked by the power apparatus played by the employer. It happens so because her being depends entirely on its benevolence. The phonic expression of this betrayal and split in the family was the opening of the door to the chief clerk. "For a moment there was silence. 'They won't open the door,' Gregor said to himself, from within some mad hope caught (befangen in irgendeiner unsinnigen Hoffnung)" (ibid., p.93, my emphasis U.I.). "But then of course, as always, the servant-girl walked with firm stride to the door and opened it" (ibid.). This mad, nonsensical hope is linked to the door and is well defined. It illustrates the hope of the child who hides himself behind the back of his parents when a schoolmaster is chastising him. It is the hope that the petty crimes committed at school won't be sanctioned back home. Alas, from the family's point of view such a decision of keeping the door closed was not only senseless but essentially mad. The door must be open, which is clear for firmly standing down to earth maids and, from then on the bond of confidence between Gregor and his family will be unsealed.

The chief clerk will make the family realize that the voice of Gregor is "the voice of an animal" and instantly pulls them on his side by saying "you don't suppose he's pulling our legs, do you?” (ibid, p.98, my emphasis U.I.). Indeed, Gregor Samsa was perhaps not exactly making a fool of everyone, but was expecting this - a "calm" reaction in the house would be foolishness from the point of view of the world. Therefore, since the door has been opened the family has been exposed to a mirror that was reflecting their stultified faces.

Through the opened door of the house and from behind the closed door of Georg the family and its metamorphosis will be subjected to a double observation. As The Letter to the Father shows Kafka was a master of looking at things taking into account opposite point of views. Kafka and its characters empathize with the lack of understanding they generate, they are masters of an empathy of alienation - they do not understand themselves as much as it is possible to misunderstand. And they understand others so much that they loose understanding for themselves. This mechanism - of which suicide is the climax - is described in the most concise way in the Judgment (Kafka, 2007).

In this novel, the father who has questioned the reality of his son's friend jumps on the bed "kicking up his legs" (ibid., p.47), while in The Metamorphosis he was "stamping his feet" unusually high and was "emitting hissing sounds like a savage" (ibid., p.104). It seems that it is on the side of the father that the metamorphosis happens and is instantaneous. From short moments of weakness in which old fathers start to move their sons, grow - so hastily that it is hard to pull oneself together - an inhuman supremacy. It is in terms of this disproportion of forces that the values are ranged. If the son is stately, the father will scream standing on his bed, if he is old and disabled he will throw curses. If the son has been metamorphosed into a beetle, the father will hiss like a wildman and this "sound to Gregor's ears was not that of one father alone" (ibid., p. 105).

The rates of closeness and strangeness are changing in a flash on both sides of the father and of the son. When they fall down to the ground of alienation, they suddenly start to surge with tenderness for the other alien creature. Therefore, a momentary affection for a weak and tired father must withdraw, when he suddenly appears in front of the son "fairly erect; wearing a smart blue uniform with gold buttons" and approaches him with "hands in his pockets [...] with an expression 
of grim resolve" (ibid., p.124). However, in the realm of rational reflection and practice of everyday life, Gregor Samsa understands his father very well, from the beginning until the end. He is ready to appreciate his prudence in the house economy, although he discovers how he has been misled. When he flees before his father, he resigns from climbing the walls or ceiling considering that "his father might interpret that as a sign of particular wickedness on his part" (ibid., p.125). This attention toward the father never stops. "[B]ut really, really, was that still his father?" (ibid., p.24). The mills of the metamorphosis help the father to reclaim the prematurely relinquished position of the head of the family. From a retired decrepit old man he returns to his posture from youth who considered it necessary to always be very strict with him. After all, Gregor's metamorphosis helps him to reclaim something that has been for Kafka the most mysterious thing - the care of the pater familias.

In the novel under this title Die Sorge des Hausvaters ("The Cares of a Head of Household" Kafka, 2007), a character appears about which the best you can say is, using the words of the cleaner, "that thing" [das Zeug], that is Odradek. Odradek a "flat star-shaped reel of thread" from which a "little rod emerges" and another "rod going off [from it] at right angles" "looks functionless but after its fashion complete" (ibid., p.211). For those who understand Slavonic languages, Odradek sounds like dissuading something to someone (Max Brod and Wilhelm Emrich have written about its etymological link with the Czech rat/rada and "udraditi" meaning disadvise). According to Harold Bloom, "Odradek is uninvited yet will not leave, since implicitly he dissuades you from doing anything about his presence, or rather something about his very uncanniness advises you to let him alone" (Bloom, 2006, p. 17). The etymology suggests dissuading everything relative to it, but also a sort of moving away from, "the prefix $o d$, meaning $a b$, 'off, away from', and in the suffix $e k$, indicating a diminutive.... Odradek...would, therefore, mean a small creature that dissuades someone from something, or rather, a creature that always dissuades in general" (Emrich, 1958, p. 92-93). But Kafka at the beginning notices that etymologies both German and Slavonic do not help to explain the meaning of this name. What has brought us close to Odradek is the father who appears in the German title - "Hausvaters". His care leading up to pain consists in the fact that Odradek could survive him and "will [...]one day tumble down the stairs before the feet of [his] children, and [...] children's children" (Kafka, 2007, p. 212). Odradek is not a son but something that seems in rivalry with the father. This conflict around the care of the head of the household family seems fundamental. Its core consists in one mechanism - the rule over closeness and estrangement - on the one hand, the capacity to alienate oneself and to understand alienation of the other, and on the other, an empathy driving one's mad. Kafka has apparently taught oneself to operate those mechanisms perfectly. Living with his father he could never drive any reaction of joy or despair till the end, because the father as a measure of all things appeared and ridiculed both. The father has therefore been the hyper-catalyzer (or rather inhibitor) of Franz Kafka's life. His appearance brings an end to all emotions or experiences in which the son was feeling alive and the life's impossibility has been forgotten. The Letter to the Father is a list of those illusions that vanish at the moment of awakening. It gives us a hint for understanding the father-animal/son relation; the father is the one whose apparent care turns into a fatal repudiation. For the son/animal's will of life, of doing his job no matter the circumstances is paralyzed by its awkwardness within the father's perspective. The call for rescue turns into a rage of depreciation and annihilation.

Why Kafka has not decided to leave his family, why didn't he find deliverance in marriage but, on the contrary, marriage was something that he feared the most? As an answer to such questions can be considered the father's reaction to the announcement of his son's engagement described in the violent scene from The Judgment. The way of salvation is blocked by an abasement of both the son and his fiancée. ["because she hoicked up her skirts like this, and like this, the disgusting slut" (Kafka, 2007, p. 47)]. Why this one and not another one? For a mostly ignoble 
reason - according to the father the inability to meet the sexual needs in a different matter. This systematic and planned humiliation reaches here the only snippet of firm land that has been grabbed in order to survive. Afterwards, there is no longer any friend, no longer any fiancée because the judgment is impossible to dismiss and is left undismissed.

The father intentionally attacks there where every argument becomes a two-edged sword and suicidally devastates more deeply. In the same way as the son from The Judgment towards the amnesiac father, Cordelia towards her father King Lear does not decide herself to raise the gauntlet that has been thrown down to her feet. They both choose silence: 'Love and be silent'. Nevertheless, the whole oeuvre of Kafka is the study of this silence - it is a postponed fall down, that has been drowned out by a passing bus - a moment of "unending flow of traffic" (Kafka, 2007, p. 50).

\section{Conclusion}

In one of the Zürau aphorisms we discover an alternative that suits our needs and concludes our crossing of philosophy and literature: "You can withdraw from the sufferings of the world - that possibility is open to you and accords with your nature - but perhaps that withdrawal is the only suffering you might be able to avoid" (Kafka, 2006, p.113). Which means that you can withdraw or maintain the distance but no other has been appointed to this task - no one will replace you. This door has been kept open only for you. There is no one else on those sand dunes where a countless swarm of beetles is lying on the back waiting for your salvation.

But equally there is none interspecies bond, there is no way of communicating, there is no natural logic in this rescue. So you may withdraw, you may give an end to your emphatic train of thought, you may find many reasons not to get involved in this beetle affair. Nevertheless, this distance, this indifference - this "foreign thing", according to Gombrowicz would be "the only suffering you might be able to avoid". The hunter Gracchus who is suspended between life and death repeats this judgment:

" $[\mathrm{N}] \mathrm{o}$ one will come to help me. If people were assigned the task of helping me, all the doors of all the houses would remain closed, all the windows would be shut, they would all lie in bed, with sheets thrown over their heads, the entire earth would be a hostel for the night. And that makes good sense, for no one knows of me, and if he did, he would have no idea of where I was staying, and if he knew that, he would not know how to help me. The thought of wanting to help me is a sickness and has to be cured with bed rest." (Kafka-online.info/the-hunter-gracchus-page4.html)

The metamorphosis effectuates a true displacement in the relationship between man and animal but what Kafka describes is not the transfiguration of man into a beetle but rather the metamorphosis that affects the family. It is the father once small and weak, once monstrous that changes from a caring one to a careless. He is the one who suddenly suspends his interest and becomes indifferent. The suspension of a mad friendliness with a swarm of beetles or one of them who occupies a room of his house is something irrevocable. The reason is that the father not only cannot fully perform his rescue. He cannot even be sure that the alien creature/s is/are suffering. The distance becomes too broad. But the suspension of sympathy, the withdrawal of rescue was the only suffering he could have avoided.

\section{Bibliography}

1. Agamben, G., 1998. Homo Sacer: Sovereign Power and Bare Life, transl. D. Heller-Roazen. Stanford: Stanford University Press. 
2. Agamben, G., 2004. The Open and the Animal. Translated from the Italian, by K. Attell. Stanford: Stanford University Press.

3. Bloom, H., 2010. Modern Critical Views: Franz Kafka. New-York: Infobase Publishing.

4. Coetzee, J.M., 2003. Elisabeth Costello. New York: Penguin Books.

5. Derrida, J., 2002. The Animal That Therefore I Am (More to Follow). Translated from the French, by D. Willis. Critical Inquiry, 28(2), pp. 369-418.

6. Emrich, W., 1958. Franz Kafka. Bonn: Athenäum.

7. Gombrowicz, W., Dziennik 1957-1961, fragment 2. 1958 IV. In: J. Kott, ed. 1989. Diary: Vol 2. Translated from the Polish, by L. Vallee. Evanston: Northwestern University Press. pp. 38-40

8. Kafka, F., 2006. The Zurau Aphorisms of Franz Kafka. Translated from the German, by M. Hofmann \& Geoffrey Brock. New York: Schocken Books.

9. Kafka, F., 2007. Metamorphosis and Other Stories. Translated from the German, by M. Hofmann. London: Penguin Books.

10. Puchner, M., 2007. Performing the Open: Actors, Animals, Philosophers. TDR/The Drama Review, 51(1), pp.21-32. 